\title{
Consensual Unions and Their Dissolution among Finnish Women Born in 1938-1969
}

\section{JARL LINDGREN}

Senior Research Associate, Docent

The Population Research Institute

\section{MARKETTA RITAMIES}

Research Associate

The Population Research Institute

\section{ANNELI MIETTINEN}

Research Assistant

The Population Research Institute

\section{Introduction}

The incidence of consensual unions varies significantly among Western countries. Many European countries and the United States represent countries in which consensual unions are quite a late phenomenon. The Scandinavian countries represent an area where living together without marriage has never been a rare phenomenon and where today living together without marriage is more common than elsewhere in the other industrialized countries.

Sweden, especially, has been a forerunner of consensual unions. At the end of the 1960 s the number of consensual unions started to go up strongly. Now they are considered legally and culturally an accepted alternative to marriage and not only a prelude to it. They lasted longer and longer and people had children in them more than before. (Bernhardt and Hoem 1985, 376; Hoem and Rennermalm 1985, 81-112).

In Denmark and Sweden the consensual union could be considered a social institution existing side by side with the institution of marriage (Trost 1988, 3). In some European countries, again, consensual unions constitute an exceptional phenomenon, being quite unusual, and against the cultural norms of the society.

In the United States it is not yet felt that the consensual union has become an alternative to marriage. It is considered the last phase of courtship. Although sociologists and demographers usually compare the experience of consensual union to marriage, in the opinion of Rindfuss and Vandenheuvel $(1990,704)$ the characteristics of those living in a consensual union resemble single people more than married couples.

The development of the Finnish society follows that of Sweden in many respects, with a certain delay. Evidently, this is also the case with consensual unions.

In Finland little study has been made of consensual unions. Some data are avail- 
able that are based on random and local investigations and some estimates of the situation on the country level. In 1978 Statistics Finland conducted a survey whose aim was to examine, among other things, the frequency of cohabiting without marriage. Since 1978 a biannual estimate of the number and some structural data of consensual unions in Finland has been published. It is based on the labor force survey where approximately 9,000 persons aged 15-64 are interviewed. The survey gives data on the total existing number of consensual unions but not on newly established unions nor on their dissolution. It goes without saying that the survey gives very little, if any, information on the changes of mode and structure of the consensual unions. In 1989, for the first time, a survey conducted by Statistics Finland gives an opportunity to get a profound overview of the typical features of the life cycle of those cohabiting without marriage. In the survey, about 4,000 women aged $22-51$ were interviewed ${ }^{1}$.

In this paper we present some preliminary empirical data on the development of consensual unions with emphasis on the frequency and pattern of entering these unions as well as their dissolution. Our main source has been the above-mentioned survey. Later on we will continue the study with a more detailed analysis and with several other variables.

\section{The Development}

Living together without marriage was rather unusual in Finland in the late 1800s and still in the early $1900 \mathrm{~s}$. Up to 1926 sexual intercourse was allowed only in marriage. However, in practice, it was rather seldom that the violators of this rule were punished. As a matter of fact, many women in the labor force lived together with their fiancé before marriage in the late 1800 s. Some of them even had a mutual child before marriage. Difficulties in getting a home of their own or other economic reasons often forced them to live in a non-marital relationship. Also, politically-conscious people entered into »companion marriages».

Quantitatively, cohabiting without marriage was very rare. Non-marital cohabitation was more common in the cities than in the rural areas. The majority of the couples lived in the provinces of Uusimaa, Turku and Pori, Häme and Vyborg (Jaakkola 1984, 34-36). At this time, when living in consensual unions was against the existing norms of society, people living in non-marital relationship included those who had not officially divorced or who could not get married because they had not been confirmed in the church.

In the 1950 s and 1960 s the number of consensual unions was still rather low, although the available information from these decades is scarce. At the end of the $1960 \mathrm{~s}$, in Tampere, 17 percent of the couples whose banns of marriage were published in the Evangelical Lutheran Church had given the same residencial address in their ap-

1 The basic population consisted of women aged 22-51 years living in households at the time of the investigation. The respondents were chosen by means of simple random sampling from data maintained by the Central Population Register. Out of the final sample of 5,105 persons, 4,155 acceptable interviews were obtained. The remaining 950 were non-respondents. The non-response rate was $18.6 \%$. The highest non-response rate was obtained in the Helsinki region, where it was $39 \%$. The most common reason was refusal or $84 \%$ of the non-responses. The absolute value of the error caused by non-response is less than one percentage point or of the same magnitude as the deviation from the basic population caused by random error in the sample. 
plication. Actually it was not until the 1970s, and especially at the end of the decade, that consensual unions began to be more common.

In a survey from 1971 concerning the sexual life of the Finns, it was stated that of all people aged 18-54, two percent cohabited without marriage, which means three percent of all couples living together in these age groups (Sievers et al. 1974). According to the marriage statistics of 1978, the proportion of the age group 15-64 who were cohabiting was five percent.

The proportion of non-marital cohabiting in the age group 15-64 doubled from 1978 to 1989 , i.e. increased from 5 to 11 percent. In 198916 percent of those cohabiting lived in a non-marital union, and therefore the proportion of consensual unions of all unions doubled during the corresponding time. In 1989 approximately 372,000 persons were living in a consensual union.

\section{At Present}

According to the 1989 survey, 14 percent of the women aged $22-51$ who were interviewed were cohabiting without marriage at the time of the interview and 18 percent of all women were living in a consensual union. The reason for the somewhat lower proportions of consensual unions mentioned above is the different population used in the surveys; the labor force survey includes younger and older age groups than the 1989 survey material, and especially in older age groups consensual unions are rare.

Non-marital cohabitation has already affected a substantially large group of women. Of all interviewed women 54 percent had either been living in a consensual union earlier or were doing so at the time of the interview. The rapid increase of consensual unions during the last few decades is clearly shown when examining birth cohorts. In the oldest cohort - those born before 1945 - only 22 percent had been cohabiting in a consensual union during some period of their life, whereas 75 percent of those born in 1960-64 had cohabited without marriage at sometime or were doing so at the time of the interview (Table 1).

Table 1. Women ever having lived in a consensual union, by birth cohorts

$\begin{array}{lccc}\text { Birth Cohorts } & \text { Age in } 1989 & \text { Percent } & \text { N } \\ 1938-1939 & 50-51 & 18.4 & 217 \\ 1940-1944 & 45-49 & 22.9 & 524 \\ 1945-1949 & 40-44 & 34.9 & 776 \\ 1950-1954 & 35-39 & 59.5 & 735 \\ 1955-1959 & 30-34 & 74.1 & 772 \\ 1960-1964 & 25-29 & 75.1 & 719 \\ 1965-1967 & 22-24 & 61.4 & 412 \\ \text { All cohorts } & & 53.7 & 4155\end{array}$

Source: Statistics Finland. Survey 1989

The increase of the proportion of consensual unions is, of course, mainly a phenomenon linked to the times. Cohabiting without marriage increased with an accelerating rate from the 1950 s up to the present time. In the 1970 s, attitudes towards sexual relationships outside marriage became less rigid. This change of atmosphere was visible in all age groups. The proportion is, of course, most accentuated among the youngest, but even among the oldest women interviewed, some were living in 
a union without marriage. In the 1980 s almost all, about $80-90$ percent of those under 30 of age, started their partnership in the 1980 s by entering into a consensual union. Twenty years earlier the corresponding proportion was less than ten percent.

Even if the proportion of women of mature age entering into a consensual union is low, only $6-8$ percent, it is not unusual for them, in a later phase of life, after their marriage had been dissolved, to live in a consensual union (Table 2).

Table 2. Consensual unions as a proportion of all conjugal unions according to the year of entering the first union and birth cohorts

\begin{tabular}{lccccc} 
Birth Cohorts & \multicolumn{6}{c}{ Year of entering the consensual union } \\
& $1954-59$ & $1960-69$ & $1970-79$ & $1980-89$ & Total \\
$1938-1939$ & 2.1 & 5.0 & 6.2 & 7.9 & 21.2 \\
$1940-1944$ & 1.2 & 9.2 & 8.8 & 5.7 & 25.0 \\
$1945-1949$ & & 8.0 & 18.6 & 10.8 & 37.4 \\
$1950-1954$ & & 2.2 & 45.2 & 15.8 & 63.2 \\
$1955-1959$ & & & 42.0 & 38.7 & 80.7 \\
$1960-1964$ & & & 7.7 & 81.3 & 89.1 \\
$1965-1969$ & \multirow{2}{*}{0.3} & 3.5 & 23.2 & 92.9 & 92.9 \\
Total & & & & 33.2 & 60.2
\end{tabular}

Source: Statistics Finland. Survey 1989.

\section{Starting Age}

During the last decades there has been a clear tendency toward a gradually growing age at entering first marriage. In the 1950s the mean age at marriage was 24.4 years and at the end of the 1980s it was 25.8 years (1989) (Csernak 1992).

The average age at entering the first consensual union among the age groups where consensual unions are most usual is almost the same during the whole period studied, probably with a small decreasing tendency. Among those aged 15-29, the median age was 21.9 in the oldest and 21.4 in the youngest time cohort (Table 3 ). In some intermediate cohorts the median age was somewhat higher, but on the whole the pattern is the same in all cohorts.

Table 3. Median age at entering first consensual union among those aged 15-29 years, by birth cohorts

Birth cohort

$1938-1944$
$1945-1949$
$1950-1954$
$1955-1959$
$1960-1964$
$1965-1967$
Median age

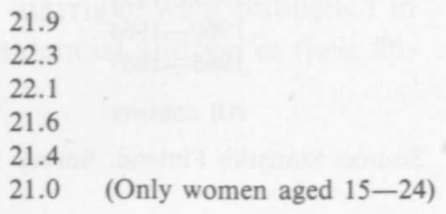

21.9

22.3

21.4

(Only women aged $15-24)$

Source: Statistics Finland. Survey 1989

One might expect that the age at first marriage among those who get married without first cohabiting would be about the same as that of entering ones first consensual union. In the beginning of the period studied, women did start cohabiting at about the same age, be it marriage or consensual union (Table 4). Gradually, how- 
ever, the difference grew, and at the end of the period, the age at marriage was 26 years and that of consensual unions roughly 24 years.

Table 4. Mean age at entering first consensual union as well as first marriage, when marriage has not been preceded by non-marital cohabitation, by year of entering union

$\begin{array}{lcccr}\text { Year of entering } & \text { Marriage } & \text { N } & \text { Consensual union } & \text { N } \\ 1954-1964 & 20.4 & 431 & 19.9 & 54 \\ 1965-1969 & 21.8 & 476 & 20.6 & 101 \\ 1970-1974 & 22.5 & 378 & 21.2 & 346 \\ 1975-1979 & 23.3 & 192 & 21.8 & 516 \\ 1980-1984 & 23.8 & 120 & 22.2 & 573 \\ 1985-1989 & 26.0 & 56 & 23.5 & 456 \\ & & 1653 & & 2046\end{array}$

Marriages are nowadays contracted later than previously. Even if the median age at entering one's first consensual union has been practically unchanged among young people during the time period covered by the survey, there should have been a rise in the average age at entering consensual unions, because consensual unions are nowadays rather common even among older age groups. However, the rise of the mean age at entering consensual unions in Table 4 is apparently somewhat exaggerated because of the age distribution of the material in the survey; the first cohorts entering consensual unions (in the 1950s) consisted only of young women while the last cohorts also include elderly women entering into their first consensual union at mature age. As cohabitation nowadays mostly starts as a consensual union it is quite logical that the difference between the age at entering consensual unions should grow towards the end of the time period studied.

\section{Ending in marriage}

Still, most consensual unions end in marriage. In the 1950 s and in the beginning of the 1960s almost all consensual unions ended in marriage or 91 percent (Table 5). Gradually, the proportion has decreased somewhat. However, it has to be remembered that the later the consensual unions have been entered, the shorter time the union has existed, and therefore the proportion of those who will get married might still increase somewhat among the youngest time cohorts.

Table 5. First consensual unions ended in marriage as a proportion of all first consensual unions, by years of entering the consensual union

$\begin{array}{lc}\text { Year of entering } & \text { Proportion (\%) } \\ 1954-1964 & 90.7 \\ 1965-1969 & 80.2 \\ 1970-1974 & 84.7 \\ 1975-1979 & 73.3 \\ 1980-1984 & 64.7 \\ 1985-1989 & 30.5 \\ \text { Source: Statistics Finland. Survey } 1989\end{array}$


The period of cohabiting before marrying has been prolonged when comparing the behavior in the 1950 s with that in the 1980 s. While those who moved in together some decades ago lived in a consensual union for only somewhat more than one year, those who did so in the beginning of the 1980s stayed together on average two and a half years before marrying (Table 6).

When comparing the proportion of women married after three and five years after entering into a consensual union, the difference between the time periods 1975-1979 and 1980-1984 was almost nil. During the period 1975-1979 69 percent legalized their relationship within three years. In 1980-1984 the proportion was 68 percent. After five years the proportions were 88 and 89 percent respectively.

The pattern might have changed in the latest period, 1985-1989, where the proportion of those married after three years was as high as 82 percent. The higher proportion during the latest time period could probably be interpreted as a sign of the change of the pattern adopted until now.

Table 6. The length (in months) of living in a consensual union before marrying, by time of entering the consensual union

$\begin{array}{lc}\text { Time of entering } & \text { Length } \\ 1954-1964 & 15 \\ 1965-1969 & 17 \\ 1970-1974 & 26 \\ 1975-1979 & 31 \\ 1980-1984 & 28 \\ 1985-1989 & 22\end{array}$

Source: Stastistics Finland. Survey 1989

\section{Children}

Even the attitudes towards having children seem to prove that consensual unions are still mainly a prelude to marriage. Most couples living in a consensual union prefer to have their children after they have married. During the period studied, only about one-tenth of the couples had their first child before they contracted their marriage, irrespective of the time period when they started their non-marital cohabitation.

The age at first childbirth has been about the same in consensual unions as in marriages. However, people do not enter into a consensual union when they are expecting a child. A great part of the few unions which have a child before they marry have it in the beginning of the consensual unions, e.g. about 40 percent of those who have moved together in the period 1975-1984 had their first child during the first year of cohabitation.

Still a rather great proportion of childbirth occurs during the first six months after the marriage is contracted. Couples behave in the same way as they have always done in the countryside in Finland; form a legal relationship when the fiancée is pregnant. About 30 percent of those who entered in a consensual union at the end of the 1950 s and in the beginning of the 1960 s had their first child within six months after the wedding. During the following five-year periods the proportion was somewhat lower, about 20 percent. Again, among those who have had their child in the consensual union almost 30 percent married within one year after the child was born. Among the rest the variation was great. It was not uncommon that they married after three or four years of even later. 
Some of those who are remaining in a consensual union, have their child in the beginning of the cohabitation. They seem to be consciously building a family within the consensual union. Others have their first child after several years of cohabitation. For them the aim of the consensual union was probably not to be the framework for a family, but they have gradually approved it as their mode of living. On the whole, the pattern among those who have children when living in a consensual union show great variations.

In spite of the fact that the consensual union still could be considered a prelude to marriage, there seems to be a tendency to remain longer and longer in the consensual union. When only two percent of those who entered into consensual unions in the period 1956-1964 had lived in a consensual union more than five years, the corresponding proportion for the five-year period $1980-1985$ was 20 percent. Evidently, staying longer in consensual unions also means that more couples choose cohabiting without marriage. Sweet and Bumpass $(1990,5)$ found in the United States that those who have lived with their partner at least three years have evidently fewer plans for marrying than those who have been living together a shorter time.

Table 7. The proportion of women still living in a consensual union five years after entering it, by years of entering the consensual union.

$\begin{array}{lc}\text { Years of entering } & \text { Proportion (\%) } \\ 1956-1964 & 1.9 \\ 1965-1969 & 5.9 \\ 1970-1974 & 13.0 \\ 1975-1979 & 17.8 \\ 1980-1984 & 20.1 \\ 1985-1989 & . .\end{array}$

Source: Statistics Finland. Survey 1989

\section{The Break-up}

It has often been shown that consensual unions break up more often than marriages (e.g. Hoem and Hoem 1988). About 17 percent of the consensual unions interviewed in the survey ended in dissolution. Of those who dissolved their union, 54 percent formed a new consensual union with another partner while 41 percent remained single and the rest married a new partner. The proportion of consensual unions which have broken up has been almost the same in all time categories studied.

In the period 1965 - 1969, when the number of consensual union was still rather low, the proportion of dissolutions was 18 percent (Table 8). In 1980-1984 it was already 20 percent. In the period $1985-1989$ it was 17 percent, but with regard to the short period those who entered in consensual unions in 1985-1989 represent, it seems probable that there will be more dissolution among them than among those who started their cohabitation in the preceding five-year period.

The dissolution frequency of consensual unions ressembles much that of marriages. However, the risk of dissolution is somewhat higher in consensual unions than in marriages. As in marriages the frequency goes up very fast during the first years of cohabitation. After 6-7 years it decreases to a very low level.

In Figure 1 the pattern of dissolution of those who entered into consensual unions in 1975-1979 and 1980-1984 is presented. The risk of dissolution is greatest in the youngest age group, those who move in together as teenagers. Of the age group 
Table 8. First consensual unions which ended in dissolution as a proportion of all first consensual unions, by year of entering the union

$\begin{array}{lcc}\text { Year of entering } & \text { Proportion }(\%) & \mathrm{N} \\ 1956-1964 & 9.3 & 54 \\ 1965-1969 & 17.8 & 101 \\ 1970-1974 & 11.6 & 346 \\ 1975-1979 & 19.0 & 516 \\ 1980-1984 & 20.4 & 573 \\ 1985-1989 & 16.9 & 456\end{array}$

Source: Statistics Finland. Survey 1989

15-19 having entered into a consensual union during the period 1980-1984, 28 percent has ended in a dissolution. The proportion is even higher than that of the same age group married in 1980, for which it was 25 percent (Lindgren and Ritamies 1992). The preceding period, 1975-1979, shows a proportion only a few percent smaller. The older age groups also have a greater proportion of break-up than marriages have.

\section{A Summary of the Trend}

Finally, we present an overview of the distribution of marital status based on the results from the survey of 1989 . Here we compare the situation between the oldest and the youngest age cohort among those where the changes from one status to another is most rapid, i.e. from fifteen to thirty years. The oldest cohort are those born in 1938-1944 and the youngest those born in 1960-1964. The data are presented in Figure 2. The changes in marital status and cohabiting behavior is striking in many

Figure 1. The dissolution frequency of consensual unions entered in 1975-1979 and $1980-1984$.
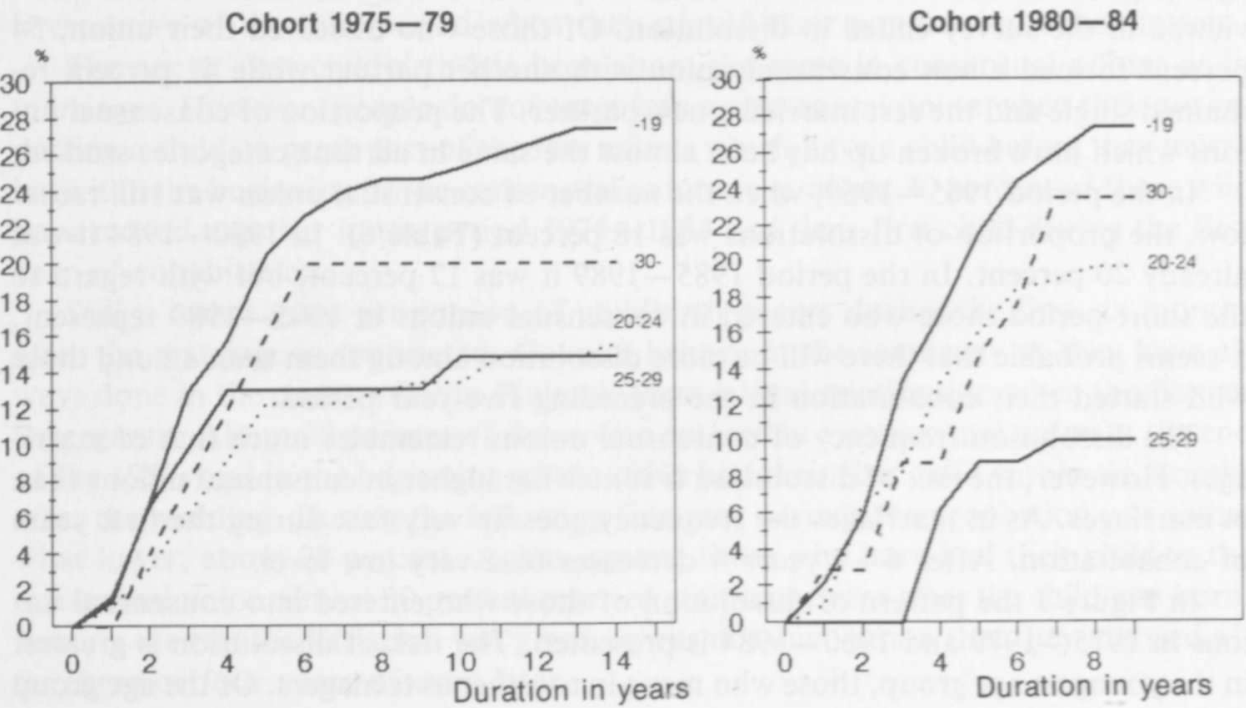

Source: Statistics Finland. Survey 1989. 
Figure 2. Living arrangement among those born in 1938-1944 and 1960-1964, aged $15-30$.

\section{Cohort born In 1938-44}

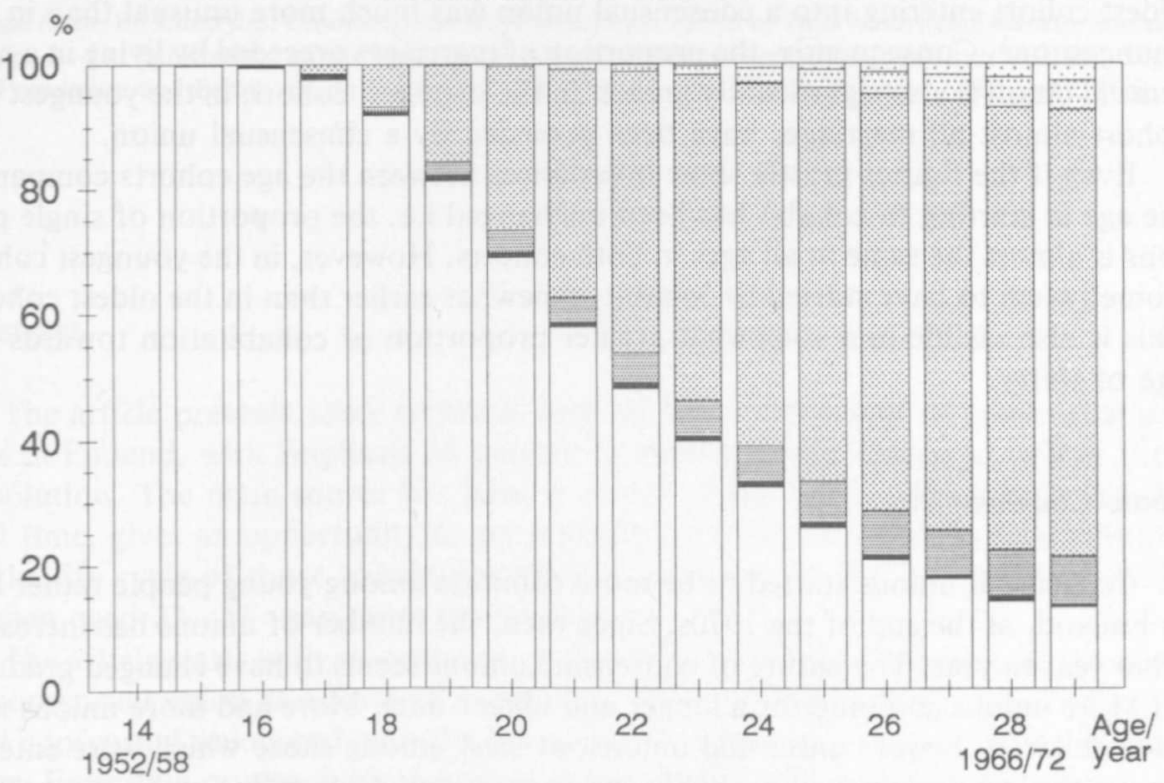

\footnotetext{
$\square$ single $\square$ 1.marriage preceeded by a consensual union 1 1.marriage - 1.consensual union 圈 divorced 2 conjugal union
}

\section{Cohort born In 1960-64}

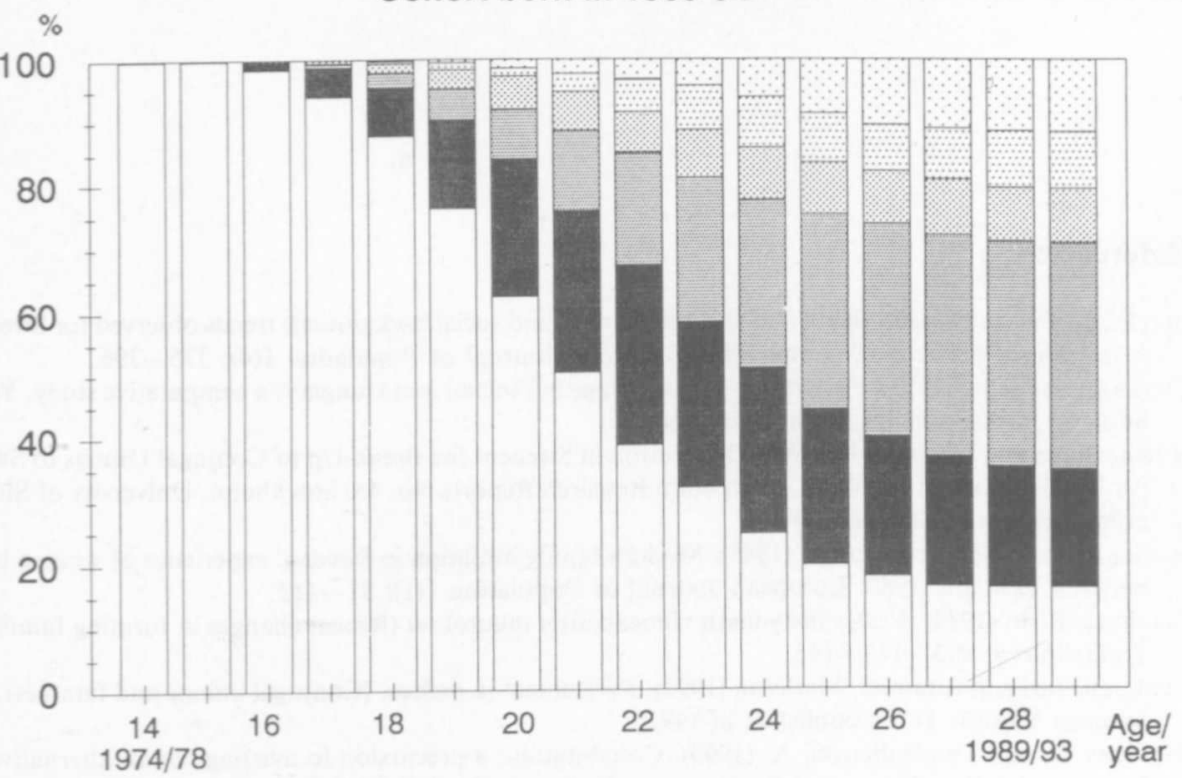

$\square$ single $\square$ 1.marriage preceeded by a consensual union $\left[\begin{array}{l}0 \\ 1 \text {.marriage }\end{array}\right.$ 1.consensual union divorced 2. conjugal union

Source: Statistics Finland. Survey 1989. 
respect. In the oldest cohort women started their cohabitation mainly by getting married, irrespective of age. In the youngest cohort, again, the corresponding proportion is much smaller: only about ten percent at the end of the period studied. In the oldest cohort entering into a consensual union was much more unusual than in the youngest one. Consequently, the proportion of marriages preceded by living in a consensual union is also significantly greater in the youngest cohort; in the youngest age cohort almost all marriages have been preceded by a consensual union.

Even if the figures mostly show invariances between the age cohorts compared, the age at starting to cohabit has been unchanged i.e. the proportion of single persons is almost the same in all ages in both cohorts. However, in the youngest cohort women seem to have started to cohabit somewhat earlier than in the oldest cohort. This is also visible in a somewhat greater proportion of cohabitation towards the age of thirty.

\section{Some Conclusions}

Consensual unions started to be more common among young people rather late in Finland, at the end of the 1970s. Since then, the number of unions has increased from year to year. The nature of consensual unions seems to have changed gradually. More unions continue for a longer and longer time. More and more unions also have children. Fewer consensual unions, at least among those which were entered during the last decade, will probably end in marriage. Cohabiting without marriage will be more and more an alternative to marriage. On the whole, consensual unions are developing into unions more or less equal to marriage.

However, the proportion is still high of those who consider the consensual union a premarital relationship is. For them consensual unions correspond more or less to the last phase of courtship, the engagement. Most people still prefer to have their children after they are inarried.

\section{References}

Bernhardt, Eva and Hoem, Britta (1985). Cohabitation and social background: trends observed for Swedish women born between 1936 and 1960. European Journal of Population 1(4): 375-396.

Csernak, Magdolna (1992). Patterns of first marriage in Finland and Hungary: a comparative study. Yearbook of Population Research in Finland 30:

Hoem, Britta and Hoem, Jan (1988). Dissolution in Sweden: the Break-Up of Conjugal Unions to Swedish Women Born in 1936-60. Stockholm Research Reports No. 45. Stockholm: University of Stockholm. Section of Demography.

Hoem, Jan and Rennermalm, Bo (1985). Modern family initiation in Sweden: experience of women born between 1936 and 1960. European Journal of Population 1(1): 81-112.

Jaakkola, Risto (1984). Perheellistymisen viimeaikaiset muutokset (Recent changes in forming families). Sosiaaliturva 72(3): 113-115.

Lindgren, Jarl and Ritamies, Marketta (1992). Parisuhteet ja perheet (Conjugal unions and families). In: Suomen Väestö. To be published in 1992.

Rindfuss, R. and Vandenheuvel, A. (1990). Cohabitation: a precursion to marriage or an alternative to being single? Population and Development Review 16(4): 703-726.

Sievers, Kai; Koskelainen, Osmo; Leppo, Kimmo (1974). Suomalainen sukupuolielämä (Sexual life of the Finns). WSOY: Porvoo.

Statistics Finland (1989). Material received in the interview survey among women aged 22-51 in 1989. 
Sweet, James A. and Bumpass, Larry L. (1990). Young Adults' Views of Marriage, Cohabitation and Family. NSFH Working Paper No. 33. Madison, Wisconsin: Center for Demography and Ecology. University of Wisconsin-Madison.

Trost, Jan (1988). Cohabitation and marriage: transitional pattern, different lifestyle, or just another legal form. In: Lifestyles, Contraception and Parenthood, edited by Hein Moors and Jeanette Schoorl, pp. 3-14, Publications of the Netherlands Interdisciplinary Demographic Institute (NIDI) and the Population and Family Study Centre (CBGS), Vol. 17. The Hague/Brussels: NIDI and CBGS.

\begin{abstract}
The article presents some emprical data on the development of consensual unions in Finland, with emphasis on pattern of entering these unions as well as their dissolution. The main source has been a survey conducted in 1989 which, for the first time, gives an opportunity to get a profound overview of the typical features of the life cycle of those cohabiting without marriage. In the survey about 4000 women aged 22-51 years were interviewed.

The article starts with an overview on the development and the present situation of consensual union as a form of cohabiting. Then it deals with the age at entering first consensual union and with the frequency of consensual unions ending in marriage. Even data on the children born in consensual unions is presented. Lastly, the dissolution pattern among consensual unions is elucidated by the authors.
\end{abstract}

